\title{
Front Matter: Volume 9861
}

"Front Matter: Volume 9861," Proc. SPIE 9861, Thermosense: Thermal Infrared Applications XXXVIII, 986101 (22 June 2016); doi:

10.1117/12.2244355

SDIE Event: SPIE Commercial + Scientific Sensing and Imaging, 2016, Baltimore, MD, United States 


\title{
PROCEEDINGS OF SPIE
}

\section{Thermosense: Thermal Infrared Applications XXXVIII}

\author{
Joseph N. Zalameda \\ Paolo Bison \\ Editors
}

18-21 April 2016

Baltimore, Maryland, United States

Sponsored by

SPIE

Co-sponsored by

FLIR Systems, Inc.

IRCameras LLC

Published by

SPIE 
The papers in this volume were part of the technical conference cited on the cover and title page. Papers were selected and subject to review by the editors and conference program committee. Some conference presentations may not be available for publication. Additional papers and presentation recordings may be available online in the SPIE Digital Library at SPIEDigitallibrary.org.

The papers reflect the work and thoughts of the authors and are published herein as submitted. The publisher is not responsible for the validity of the information or for any outcomes resulting from reliance thereon.

Please use the following format to cite material from these proceedings:

Author(s), "Title of Paper," in Thermosense: Thermal Infrared Applications XXXVIII, edited by Joseph N. Zalameda, Paolo Bison, Proceedings of SPIE Vol. 9861 (SPIE, Bellingham, WA, 2016) Six-digit Article CID Number.

ISSN: 0277-786X

ISSN: 1996-756X (electronic)

ISBN: 9781510601024

Published by

SPIE

P.O. Box 10, Bellingham, Washington 98227-0010 USA

Telephone +1 3606763290 (Pacific Time) · Fax +1 3606471445

SPIE.org

Copyright (C) 2016, Society of Photo-Optical Instrumentation Engineers.

Copying of material in this book for internal or personal use, or for the internal or personal use of specific clients, beyond the fair use provisions granted by the U.S. Copyright Law is authorized by SPIE subject to payment of copying fees. The Transactional Reporting Service base fee for this volume is $\$ 18.00$ per article (or portion thereof), which should be paid directly to the Copyright Clearance Center (CCC), 222 Rosewood Drive, Danvers, MA 01923. Payment may also be made electronically through CCC Online at copyright.com. Other copying for republication, resale, advertising or promotion, or any form of systematic or multiple reproduction of any material in this book is prohibited except with permission in writing from the publisher. The CCC fee code is 0277-786X/16/\$18.00.

Printed in the United States of America.

Publication of record for individual papers is online in the SPIE Digital Library.

\section{SPIE. DIGITAL}

Paper Numbering: Proceedings of SPIE follow an e-First publication model. A unique citation identifier (CID) number is assigned to each article at the time of publication. Utilization of CIDs allows articles to be fully citable as soon as they are published online, and connects the same identifier to all online and print versions of the publication. SPIE uses a six-digit CID article numbering system structured as follows:

- The first four digits correspond to the SPIE volume number.

- The last two digits indicate publication order within the volume using a Base 36 numbering system employing both numerals and letters. These two-number sets start with $00,01,02,03,04$, $05,06,07,08,09,0 A, 0 B \ldots$ OZ, followed by 10-1Z, 20-2Z, etc. The CID Number appears on each page of the manuscript. 


\title{
Contents
}

\author{
vii Authors \\ ix Conference Committee \\ xi Introduction
}

ADDITIVE MANUFACTURING AND PROCESSING INDUSTRIES

986102 In-process thermal imaging of the electron beam freeform fabrication process (Invited Paper) [9861-1]

986103 Four-color imaging pyrometer for mapping temperatures of laser-based metal processes [9861-2]

986104 Multiple sensor detection of process phenomena in laser powder bed fusion [9861-3]

986106 Assessing the use of an infrared spectrum hyperpixel array imager to measure temperature during additive and subtractive manufacturing [9861-5]

986107 Calibrating IR cameras for in-situ temperature measurement during the electron beam melt processing of Inconel 718 and Ti-Al6-V4 [9861-6]

ROBOTIC SCANNING AND REMOTE SENSING

986109 Advances in in situ inspection of automated fiber placement systems [9861-8]

9861 OA Thermal and visible remote sensing for estimation of evapotranspiration of rainfed agrosystems and its impact on groundwater in SE Australia [9861-9]

$9861 \mathrm{OB}$ Prediction of tomato freshness using infrared thermal imaging and transient step heating [9861-10]

\section{VIBRO-THERMOGRAPHY AND NONDESTRUCTIVE TESTING}

9861 OE Application of burst vibrothermography to characterize planar vertical cracks (Best Paper Award) [9861-12]

9861 OF Evaluating impact damage in graphite epoxy composite by using low-power vibrothermography [9861-13]

9861 OG Combining passive thermography and acoustic emission for large area fatigue damage growth assessment of a composite structure [9861-14] 
$9861 \mathrm{OH}$ Infrared thermography for CFRP inspection: computational model and experimental results [9861-15]

\section{NONDESTRUCTIVE TESTING AND COMPOSITES}

9861 0l Active thermal NDT: problems and solutions [9861-16]

9861 0J IR thermography for the assessment of the thermal conductivity of thermoelectric modules at intermediate temperature [9861-17]

9861 OK Fracture behavior of reinforced aluminum alloy matrix composites using thermal imaging tools [9861-18]

$9861 \mathrm{OL}$ Superimpose signal processing method for micro-scale thermal imaging of solar salts at high temperature [9861-19]

9861 OM Optimizing components and evaluating technical performance of IR thermographic NDT systems [9861-20]

THERMAL MODELING AND SIGNAL PROCESSING

9861 ON Simulation of thermographic responses of delaminations in composites with quadrupole method (Invited Paper) [9861-21]

986100 Regression analysis of non-contact acousto-thermal signature data [9861-22]

9861 OP Comparison of time and frequency behavior in TSR and PPT evaluation [9861-23]

9861 OR Tracking composite material damage evolution using Bayesian filtering and flash thermography data [9861-25]

9861 OS Thermography and k-means clustering methods for anti-reflective coating film inspection: scratch and bubble defects [9861-26]

\section{BUILDING MATERIALS AND INFRASTRUCTURE APPLICATIONS}

9861 OT Classification of electrical problems detected by infrared thermography using a risk assessment process [9861-27]

9861 OU Flame attenuation effects on surface temperature measurements using IR thermography [9861-28]

$98610 \mathrm{~V}$ Thermographic measurement of thermal bridges in buildings under dynamic behavior [9861-29]

9861 OW Automatic thermographic scanning with the creation of 3D panoramic views of buildings (Best Student Paper Award) [9861-30] 
9861 0X Building thermography: reporting and interpretation of results [9861-33]

\section{DETECTORS AND IMAGING SYSTEMS}

$98610 Z$ Toward DMD illuminated spatial-temporal modulated thermography [9861-35]

986110 Non-destructive testing of mid-IR optical fiber using infrared imaging [9861-36]

986111 Wide dynamic logarithmic InGaAs sensor suitable for eye-safe active imaging [9861-37]

986112 A simple blackbody simulator with several possibilities and applications on thermography [9861-38]

986113 IR camera system with an advanced image processing technologies [9861-48]

\section{BIOLOGICAL AND MEDICAL APPLICATIONS}

986115 Standardization of infrared breast thermogram acquisition protocols and abnormality analysis of breast thermograms [9861-40]

986116 Pain related inflammation analysis using infrared images [9861-41]

986117 IR camera temperature resolution enhancing using computer processing of IR image [9861-42]

\section{REMOTE AND MULTI-DISCIPLINE IMAGING}

986118 Mineral identification in hyperspectral imaging using Sparse-PCA [9861-43]

986119 Evaluation of terrestrial photogrammetric point clouds derived from thermal imagery [9861-44]

9861 1A A comparative study of experimental and finite element analysis on submillimeter flaws by laser and ultrasonic excited thermography [9861-45]

9861 1B Nondestructive evaluation technique using infrared thermography and terahertz imaging [9861-46]

\section{POSTER SESSION}

9861 1C Emissivity retrieval from indoor hyperspectral imaging of mineral grains [9861-47] 
Proc. of SPIE Vol. $9861986101-6$

Downloaded From: https://www.spiedigitallibrary.org/conference-proceedings-of-spie on 26 Apr 2023 Terms of Use: https://www.spiedigitallibrary.org/terms-of-use 


\title{
Authors
}

Numbers in the index correspond to the last two digits of the six-digit citation identifier (CID) article numbering system used in Proceedings of SPIE. The first four digits reflect the volume number. Base 36 numbering is employed for the last two digits and indicates the order of articles within the volume. Numbers start with 00, 01, 02, 03, 04, 05, 06, 07, 08, 09, 0A, 0B...0Z, followed by 10-1Z, 20-2Z, etc.

\author{
Abi-Ramia, Marco Antônio, 12 \\ Arion, Bogdan, 11 \\ Avdelidis, N. P., OK \\ Bardhan, Shawli, 16 \\ Beaudoin, Georges, 18, $1 \mathrm{C}$ \\ Bhattacharjee, Debotosh, 15, 16 \\ Bhowmik, Mrinal Kanti, 15, 16 \\ Bison, P., OJ, OV \\ Boldrini, S., OJ \\ Bortolin, A., OV, OW \\ Bouvier, Christian, 11 \\ Burke, Eric R., 02, OG \\ Cadelano, G., OV, OW \\ Celorrio, Ricardo, $\mathrm{OE}$ \\ Chamberland, Martin, 18, 1C \\ Chulkov, A. O., OM \\ Cifuentes, Ángel, OE \\ Cramer, K. Elliott, 09, ON \\ Criner, Amanda, 00 \\ Dagel, Daryl J., 03 \\ Das, Kakali, 15, 16 \\ De Carli, M., OV \\ de Vries, Jaap, OU \\ Dehoff, R. R., 07 \\ Derusova, D. A., OF \\ Dinwiddie, R. B., 07 \\ Domack, Christopher S., 02 \\ dos Santos, Laerte, 12 \\ Druzhinin, N. V., OF \\ Exarchos, D., OK \\ Fabrizio, M., OJ \\ Farley, Vincent, 10 \\ Fernandes, Henrique $\mathrm{C} ., \mathrm{OH}, \mathrm{IA}$ \\ Ferrarini, G., OV, OW \\ Ferrario, A., OJ \\ Fortin, Vincent, 10 \\ Gagnon, Marc-André, 10 \\ Genest, Marc, 1A \\ Ghosh, Anjan Kumar, 15 \\ Gogoi, Usha Rani, 15 \\ Gregory, Elizabeth D., OR \\ Grossetete, Grant D., 03 \\ Guyot, Éric, 10 \\ Hafley, Robert A., 02 \\ Hassler, Ulf, $1 \mathrm{~A}$ \\ Heigel, Jarred, 06 \\ Holland, Steve D., OR \\ Horne, Michael R., OG \\ Howell, Patricia A., ON
}

Hsieh, Sheng-Jen (Tony), OB, OS

Huff, Roy, OT

Huot, François, 18, 1C

Ibarra-Castanedo, Clemente, $\mathrm{OH}, \mathrm{OK}, 18,1 \mathrm{C}$

Iwama, Tatsuya, 1B

Joncas, Simon, 1A

Juarez, Peter D., 09

Kato, Yukitaka, OL

Kauppinen, T., OX

Kinzel, Edward C., $\mathrm{OZ}$

Kirka, M. M., 07

Korey, Scott P., 03

Lagueux, Philippe, 10

Lalonde, Erik, 18, 1C

Lane, Brandon, 04, 06

Lemos, Alisson Maria, 12

Lloyd, P. D., 07

López, Fernando, $\mathrm{OH}$

Lowe, L. E., 07

MacCallum, Danny $0 ., 03$

Madaras, Eric I., OG

Majumdar, Gautam, 15

Maldague, Xavier P. V., OH, OK, 18, 1A, $1 \mathrm{C}$

Marcotte, Frédérick, 10

Marlow, G. S., 07

Matikas, T. E., OK

Mclntosh, Gregory B., OT

Mendioroz, Arantza, OE

Metcalf, Jeremy P., 19

Miozzo, A., OJ

Montagner, F., OJ

Morikawa, Junko, OL

Morioka, Karen, $\mathrm{OH}$

Moylan, Shawn, 04, 06

Nath, Satyabrata, 16

$\mathrm{Ni}$, Yang, 11

Noguier, Vincent, 11

Ohkubo, Syuichi, 13

Olsen, Richard C., 19

Oswald-Tranta, B., OP

Paloniitty, S., OX

Pawar, S. S., OM

Pribe, Joshua D., $0 Z$

Robitaille, François, $1 \mathrm{~A}$

Roohi, Rakhshan, 0A

Sakagami, Takahide, 1B

Salazar, Agustín, OE

Schehl, Norman, 00

Seebo, Jeffrey P., 09 
Sfarra, S., OK

Sheng, Yunlong, 1A

Shiozawa, Daiki, 1B

Siikanen, S., OX

Sojasi, Saeed, 18, 1C

Tabinowski, Robert, OU

Tamaki, Yoshitaka, 1B

Taminger, Brian L., 02

Taminger, Karen M., 02

Tamura, Tetsuo, 13

Tan, Zuojun, OB

Tarpani, José R., $\mathrm{OH}$

Thandu, Srinivas $\mathrm{C} ., \mathrm{OZ}$

Trofimov, Vladislav $\vee ., 17$

Trofimov, Vyacheslav A., 17

Vallée, Réal, 10

Vavilov, V.P., OF, OI, OM

Vazquez, P., OK

Wang, Hongjin, OB, OS

Webb, John A., OA

Whitenton, Eric, 04, 06

Winfree, William $\mathrm{P} ., \mathrm{ON}$

Xie, Jing, OB

Yin, Zhaozheng, $0 Z$

Yousefi, Bardia, 18, 1C

Yu, Lingyao, $1 \mathrm{~A}$

Zalameda, Joseph N., 02, 0G, ON

Zamengo, Massimiliano, OL

Zatón, Lander, $\mathrm{OE}$

Zhang, Hai, $\mathrm{OH}, \mathrm{IA}$

Zhang, Jian, $O B$

Zhou, Xunfei, OS 


\section{Conference Committee}

Symposium Chair

Ming C. Wu, University of California, Berkeley (United States)

Symposium Co-chair

Majid Rabbani, Eastman Kodak Company (United States)

Conference Chair

Joseph N. Zalameda, NASA Langley Research Center (United States)

Conference Co-chair

Paolo Bison, Consiglio Nazionale delle Ricerche (Italy)

Conference Program Committee

Andrea Acosta, Colbert Infrared Services (United States)

Nicolas Avdelidis, National Technical University of Athens (Greece)

Jeff R. Brown, Embry-Riddle Aeronautical University (United States)

Douglas Burleigh, La Jolla Cove Consulting (United States)

Fred P. Colbert, Colbert Infrared Services (United States)

K. Elliott Cramer, NASA Langley Research Center (United States)

Jaap de Vries, FM Global (United States)

Ralph B. Dinwiddie, Oak Ridge National Laboratory (United States)

Sheng-Jen (Tony) Hsieh, Texas A\&M University (United States)

Herbert Kaplan, Honeyhill Technical Company (United States)

Timo T. Kauppinen, VTT Technical Research Center of Finland (Finland)

Dennis H. LeMieux, Siemens Power Generation, Inc. (United States)

Monica Lopez Saenz, IRCAM GmbH (Germany)

Gregory B. McIntosh, Teasdale Consultants Ltd. (Canada)

Xavier P. V. Maldague, University Laval (Canada)

Junko Morikawa, Tokyo Institute of Technology (Japan)

Gary L. Orlove, FLIR Systems, Inc. (United States)

Beata Oswald-Tranta, Montan Universität Leoben (Austria)

G. Raymond Peacock, Temperatures.com, Inc. (United States)

Piotr Pregowski, Pregowski Infrared Services (Poland)

Ralph A. Rotolante, Vicon Enterprises Inc. (United States)

Andres E. Rozlosnik, SI Termografía Infrarroja (Argentina)

Morteza Safai, The Boeing Company (United States)

Takahide Sakagami, Kobe University (Japan) 
Steven M. Shepard, Thermal Wave Imaging, Inc. (United States)

Sami Siikanen, VTT Technical Research Center of Finland (Finland)

Gregory R. Stockton, Stockton Infrared Thermographic Services, Inc. (United States)

Vladimir P. Vavilov, Tomsk Polytechnic University (Russian Federation)

\section{Session Chairs}

1 Vendor Presentations and Reception: Infrared Applications

Andres E. Rozlosnik, SI Termografía Infrarroja (Argentina)

Sheng-Jen (Tony) Hsieh, Texas A\&M University (United States)

2 Additive Manufacturing and Processing Industries

Ralph B. Dinwiddie, Oak Ridge National Laboratory (United States)

Gregory B. McIntosh, Teasdale Consultants Ltd. (Canada)

3 Robotic Scanning and Remote Sensing

Beata Oswald-Tranta, Montan Universität Leoben (Austria)

Junko Morikawa, Tokyo Institute of Technology (Japan)

$4 \quad$ Vibro-Thermography and Nondestructive Testing

Vladimir P. Vavilov, Tomsk Polytechnic University (Russian Federation)

Andres E. Rozlosnik, SI Termografía Infrarroja (Argentina)

5 Nondestructive Testing and Composites

Paolo Bison, Consiglio Nazionale delle Ricerche (Italy)

Nicolas P. Avdelidis, National Technical University of Athens (Greece)

6 Thermal Modeling and Signal Processing

Steven M. Shepard, Thermal Wave Imaging, Inc. (United States)

Jaap de Vries, FM Global (United States)

$7 \quad$ Building Materials and Infrastructure Applications

Xavier Maldague, University Laval (Canada)

Gregory R. Stockton, Stockton Infrared Thermographic Services, Inc.

(United States)

8 Detectors and Imaging Systems

Sheng-Jen (Tony) Hsieh, Texas A\&M University (United States)

9 Biological and Medical Applications

Ralph A. Rotolante, Vicon Enterprises Inc. (United States)

10 Remote and Multi-Discipline Imaging

Takahide Sakagami, Kobe University (Japan)

Jaap de Vries, FM Global (United States) 


\section{Introduction}

The SPIE Thermosense conference continues to be the oldest and one of the leading international technical conferences focused on scientific, industrial and general uses of infrared imaging, infrared temperature measurements, and image analysis. This annual conference met in Baltimore, Maryland, 17-21 April 2016, and had 51 abstracts submitted, 44 scientific papers presented, and an additional 16 presentations in the vendor session. The presentations comprised 15 different countries (Australia, Austria, Brazil, Canada, China, Finland, France, Greece, India, Italy, Japan, the Russian Federation, Spain, Taiwan and the United States).

In these proceedings, you will find an unequaled depth and breadth of technical information and reference data from worldwide leaders in the application, research, and industrial experts in the field of thermal imaging. The session topics included additive manufacturing, robotic scanning and remote sensing, vibro-thermography, nondestructive testing and composites, thermal modeling and signal processing, building materials and infrastructure applications, detectors and imaging systems, biological and medical applications and remote and multi-discipline imaging. I would like to thank the conference sponsors FLIR Systems, Inc. and IRCameras LLC, for the Best Paper Award and Best Student Paper Award, respectively.

I am especially excited to see new research presented in the areas of additive manufacturing and robotic scanning for composites fabrication. Additive manufacturing and robotic scanning for composites fabrication are a growing field with many potential applications, however the field has its challenges of repeatability, closed loop control, and real time defect inspection. Thermography offers a natural solution since these processes require heat during the build process. It will be exciting to see the solutions develop as they are undoubtedly presented at future Thermosense conferences.

I would also like to mention the 40th Anniversary, which will come up in a couple more years. This meeting will return back to Orlando, Florida in 2018. This city has been the traditional location of Thermosense for roughly 30 years. It is hoped that many past conference attendees and committee members will attend and help to celebrate 40 years of existence.

I would like to mention Andres Rozloznik for his work in leading the vendor session, his overall help in the conference, and his recognition by SPIE for many years of membership and involvement. I would also like to thank the previous chair Sheng-Jen (Tony) Hsieh for his past efforts in Thermosense 2015 and Paolo Bison as conference co-chair for 2016. 
Additionally, I would like to thank the committee for entrusting me with chairing the 2016 conference. The support over the past 2 years from the committee and colleagues has made it a rewarding experience. I also want to thank my wife Anita for her support during my travels. As the conference goes forward I want to encourage future conference chairs and committee members to embrace the challenge, take personal ownership, and enjoy the experience of forwarding the rich tradition of Thermosense, setting the example for many successful years to come.

Joseph N. Zalameda 